\title{
Portfolio-Based Assessment in English Language Learning: Highlighting the Students' Perceptions
}

\author{
Ahmad Syamsul Ma' arif ${ }^{1}$, Fuad Abdullah ${ }^{1}$, Asri Siti Fatimah ${ }^{1}$ and Arini Nurul Hidayati ${ }^{1}$ \\ ${ }^{1}$ Siliwangi University \\ email: maarif.syam97@gmail.com \\ email: fuad.abdullah182@gmail.com \\ email: asrisitifatimah@unsil.ac.id \\ email: arininurul@unsil.ac.id
}

\begin{abstract}
Portfolio-based Assessment (hereafter, PBA) plays an indispensable role in language assessment. PBA represents the development of the students' learning process outcomes, trains autonomous learning, and stimulates metacognitive awareness. Conversely, a few investigative attempts, addressed the students' perceptions of PBA in the Indonesian EFL Context. Therefore, this study aimed to decipher the perceptions of EFL students in Indonesia on PBA use in the English subject. Empirically speaking, two female students were involved as the participants in this study. The data were collected through a semistructured interview and analyzed with Thematic Analysis (TA) (Braun \& Clarke, 2006). The findings revealed that students articulated their perceptions in three major themes, namely developing self-monitoring from the students' learning processes, generating discipline, responsible and autonomous language learning attitudes, and mitigating perceptual mismatches among teachers and students. Pedagogically speaking, this study indicates that PBA employment can provide opportunities for students to monitor their learning progress, and enhance their self-confidence and learning motivation
\end{abstract}

Keywords: Assessment, Portfolio-Based Assessment, EFL Students'Perception.

\begin{abstract}
Abstrak
Penilaian Berbasis Portofolio (selanjutnya disebut PBP) memainkan peran yang sangat diperlukan dalam penilaian bahasa. PBP merepresentasikan perkembangan hasil proses belajar peseta didik, melatih pembelajaran otonom, dan menstimulasi kesadaran metakognitif. Sebaliknya, sedikit penelitian berfokus pada persepsi peserta didik tentang PBP dalam konteks pembelajaran Bahasa Inggris sebagai Bahasa asing. Oleh karena itu, penelitian ini bertujuan untuk menguraikan persepsi peserta didik di Indonesia tentang penggunaan PBP dalam mata pelajaran Bahasa Inggris. Secara empiris, dua peserta didik dilibatkan sebagai partisipan dalam penelitian ini. Pengumpulan data dilakukan melalui wawancara semi terstruktur dan dianalisis dengan Analisis Tematik (TA) (Braun \& Clarke, 2006). Temuan penelitian mengungkapkan bahwa peserta didik mengartikulasikan persepsi mereka dalam dua tema besar, yaitu mengembangkan pemantauan diri proses belajar peserta didik, menghasilkan sikap belajar bahasa yang disiplin, bertanggung jawab dan otonom,
\end{abstract}


serta mengurangi ketidaksesuaian persepsi antara guru dan siswa. Secara pedagogis, penelitian ini menunjukkan bahwa penggunaan PBP dapat memberikan kesempatan kepada peserta didik untuk memantau kemajuan belajar, meningkatkan kepercayaan diri dan motivasi belajar mereka.

Kata Kunci: Penilaian, Penilaian Berbasis Portofolio, Persepsi Peserta Didik sebagai Penutur Asing Bahasa Inggris

\section{INTRODUCTION}

Portfolio-based Assessment (hereafter, PBA) has an established history in L1 English where English is widely communicated as the first language. While several studies have recognized the potentials of PBA in an ESL or EFL context. Relevant literature reviews have concluded that most PBA studies related to English as L1 not in the context of ESL or EFL (Hamp-Lyons, 2001; Vass \& Kiss, 2020; Desyatova, 2020; Syzdykova, Koblandin, Mikhaylova, \& Akinina, 2021). In a similar vein, Swicegood (2015) stated that portfolios offer a viable alternative to the traditional practices applied to assess students from diverse backgrounds. In particular, the portfolio contains pieces of information systematically accumulated from the various domains within a comprehensive assessment process. With this in mind, PBA intends to assess students more holistically, view their learning, and encourage meta-cognitive and independent attitudes to learning (Nezakatgoo, 2011; Arrafii, 2021; Segaran \& Hasim, 2021).

In the same way, Liu (2003) illustrates that PBA allows students to gain some control over the assessment process. Besides, it functions to demonstrate more complete information about students. Furthermore, PBA encourages students to assess their progress and development concerning standards, reflect on the work included in their portfolios, and compare and contrast their earlier efforts with more recent works (Han, Blank \& Berson, 2020). In other words, PBA stimulates students to perform reflective statements.

Through reflective statements, students learn to evaluate their academic performances by explaining what was pivotal about the included evidence and what it said about them as learners (García, 2020). Reflective statements also revealed changes in their attitudes and feelings possessed by students concerning their abilities to succeed in an academic environment or goals for future development. As a result, portfolios encourage students to take more responsibility for their learning and to become autonomous learners (Aghazadeh \& Soleimani, 2020).

The current Western education system encourages students' independence to set their own goals, reflect on, take responsibility for their learning, and become independent learners (Liu, 2003). In Indonesia, independent or studentcentered learning has also been organized in a curriculum setting. Harosid (2019) contends that learning objectives that should be achieved by the curriculum are character quality, competence, and literacy. Students are guided by teachers to be able to adapt to the curriculum, think critically, creatively, communicatively, and collaboratively. In addition, they are also motivated to improve literacy skills in 
various aspects (Hidayati, Dewi, Nurhaedin \& Rosmala, 2020)

More technically, Hanifa (2017) contextualizes that curriculum 2013-based portfolios are classified into two major educational levels, namely junior and senior high school portfolios. To begin with, junior high school portfolios cover a number of contents, such as announcements, posters, birthday invitations, presenting results, procedure texts, events of the day \& journal diaries (recount texts), and drama projects. Next, in senior high school portfolios, students are commonly guided to collect posters, invitation cards, interview records expressions of advice, expressions of opinion mind mapping the concept of learning materials, and comics (narrative texts). Although those contents offer valuable contributions to facilitate students in designing their portfolios, the contents of a portfolio can also encompass artworks, video, or audiotape recordings of students' oral production and other virtual language learning products (Brown, 2001). In other words, the twenty-first-century education does not only accentuate to enhance students' reading and writing skills as the target of literacy cultivation (e.g. printed texts) but also foster their multimodal literacy covering the abilities to comprehend, conceptualize and produce multimodal texts (e.g. PowerPoint presentations, Web pages, videos, social media, and other digital platforms) (Martínez-Lirola, 2018; Tandiana, Abdullah \& Saputra, 2020).

Previously, other researchers have investigated PBA practices. A study in one French immersion classroom in a writing program found prominent improvements in students' writing skills (Armstrong, 2011). Besides, Lam (2014) argued that PBA enabled students to increase their learning autonomy. Moreover, PBA was assumed to be able not only to stimulate their independent learning but also to equip them with skills in evidence-based assessment practice models (Sidebotham, Baird, Walters, \& Gamble, 2018). Further, Lam (2015) also claimed that PBA can be used by teachers as input to enhance the teaching-learning process and by students as learning tools to monitor their growth. In a similar vein, Bataineh \& Obeiah (2016) examined the potential effects of PBA saving teacher time in assessing and leading more interaction and negotiation effectively. Further, Farahian \& Avarzamani (2018) also examined that PBA motivated students' metacognitive awareness in writing skills.

In Indonesia, Efendi, Usman, Muslem (2017) examined the application of portfolio assessment to students' writing skills and their responses. They testified that the execution of portfolio assessment fostered their writing skills. Equally important, it boosted them to have positive responses towards their writing reviews (e.g. increased motivation on the reviewed writing tasks).

Additionally, Sulistyo, Eltris, Mafulah, Budianto, Saiful, \& Heriyawati (2020) focused on scrutinizing the implementation of portfolio assessment and its impacts on students' writing ability and their attitudes towards it. The findings revealed that the students' writing abilities were enhanced after the implementation of the portfolio assessment. Additionally, their knowledge about content and organization considerably developed rather than grammar, vocabulary, and mechanics. Regarding the attitudes, students demonstrated positive attitudes towards the deployment of the portfolio assessment. 
Another scrutiny was carried out by Tyas (2020). She probed the employment of portfolio assessment to promote students' autonomous learning in one of the reputable universities in Indonesia. She reported that portfolio assessment enabled students to be autonomous learners because it encourages them to perform self-evaluation and reflection, supports them to engage in peer review practices, and raises their awareness of their limitations.

However, there is still little attention about the utilization of PBA in the Indonesian EFL milieu, notably in relation to the students' perceptions on the employment of PBA in English language learning practices. Therefore, to fill this void, this current study seeks to delineate the perceptions of EFL students in Indonesia of their perceptions on the employment of PBA.

\section{METHODS}

A descriptive case study was exerted as the research method. Yin (2003) notes that a descriptive case study strives to document the procedures of a particular event. Also, a descriptive case study sets to describe the natural phenomena occurring within the data in question (Zainal, 2007; Baxter \& Jack, 2008). The consideration of applying this research method is because it can naturally decipher the students' perceptions in implementing PBA.

This study was conducted in one of the junior high schools in Tasikmalaya, West Java where English was served as a foreign language (EFL). Two female students from a junior high school took part as the participants of this study. Their ages range from 13 to 14 years old. They communicate in Sundanese as the first language (L1), Bahasa Indonesia as the second language (L2), and English as the foreign language
(FL). They have experienced learning with PBA during English language learning for approximately one semester.

Several considerations emerged to recruit them as the participants. To illustrate, they actively engaged during the assessment process of learning English through PBA. In addition, the phenomenon of English teachers utilizing PBA to evaluate students' learning processes and outcomes occurred in this research context. The investigative setting (a secondary school level) supported to raise the research novelty, notably in portraying to delineate the EFL students' perceptions on the deployment of PBA during English language learning. More importantly, they agreed to participate in this study as an effort to maintain ethical considerations in conducting an empirical investigation.

The data were collected through a semi-structured interview. The semistructured interview was selected since it enables researchers to collect the information from individuals (e.g. their practices, beliefs, or opinions) (Cohen, 2006; Harrel and Bradley, 2012; Butrina, Le Vine, Henao, Sperling \& Young, 2020).

The data were analyzed by utilizing Thematic Analysis (TA). Boyatzis (1998) defines TA as "a way of seeing" and "making sense out of seemingly unrelated material". In this sense, TA functions to identify, analyze and report patterns (themes) within data (Braun \& Clarke, 2006). Briefly stated, TA was deployed because it can provide an opportunity to comprehend the potential issues more widely (Marks \& Yardley, 2004; Xu \& Zammit, 2020). 


\section{FINDINGS AND DISCUSSION}

After analyzing the data thematically. Three major themes represent the students' perceptions on the use of Portfolio-based Assessment, namely developing selfmonitoring from the students' learning processes, generating discipline, responsible and autonomous language learning attitudes, and mitigating perceptual mismatches among teachers and students. More specific elaborations are presented subsequently.

\section{Developing Self-Monitoring from the Students' Learning Processes \\ Learning experiences are one of the} pivotal elements developing the students' self-monitoring. In this case, they were able to identify their strengths and weaknesses in English language learning practices. Student \# 1 perceived that she was aware of evaluating her assignments when performing writing tasks through PBA.

Table 1: The extracts of developing selfmonitoring from the students' learning processes.

\begin{tabular}{|c|c|}
\hline Participants & Extracts \\
\hline Student \# 1 & $\begin{array}{l}\text { I felt that PBA allowed me to be } \\
\text { more aware of my works. For } \\
\text { example, when I was required } \\
\text { to do writing tasks about } \\
\text { making invitation cards, I } \\
\text { experienced several activities } \\
\text { to accomplish my cards, such as } \\
\text { finding out appropriate ideas, } \\
\text { drafting, revising, editing and } \\
\text { publishing. These words were } \\
\text { repeatedly uttered by my } \\
\text { English teacher when we } \\
\text { learned to write. Besides, he } \\
\text { reminded us to be aware of our } \\
\text { grammar, vocabulary choice, } \\
\text { and sentence structure. This } \\
\text { knowledge we gained from the } \\
\text { reviewed portfolios. Overall, } \\
\text { this PBA was really helpful for } \\
\text { us to learn from our }\end{array}$ \\
\hline
\end{tabular}

\begin{tabular}{|c|c|}
\hline & $\begin{array}{l}\text { experiences, and his valuable } \\
\text { feedback } \\
\text { (Semi-structured interview, } \\
\left.\text { August } 12^{\text {th }}, 2020\right) .\end{array}$ \\
\hline Student \# 2 & $\begin{array}{l}\text { In my opinion, PBA facilitated } \\
\text { me to have good control of my } \\
\text { writing tasks since it enables } \\
\text { me to check and recheck my } \\
\text { works repeatedly. For } \\
\text { instance, when I felt that I had } \\
\text { made it correctly, I was } \\
\text { suggested by my English } \\
\text { teacher to recheck my } \\
\text { previous reviewed } \\
\text { assignments on the same } \\
\text { topics. As a result, I found that } \\
\text { I should revise my work } \\
\text { because of any grammatical } \\
\text { errors, erroneous sentence } \\
\text { structures, and inappropriate } \\
\text { word choice. } \\
\text { (Semi-structured interview, } \\
\text { August } 12^{\text {th }}, 2020 \text { ). }\end{array}$ \\
\hline
\end{tabular}

Referring to the abovementioned extract, student \# 1 underwent a number of learning activities when she was learning to make an invitation card. As a matter of fact, she was capable of generating ideas to write, drafting, revising, editing, and even publishing her invitation card ("I experienced several activities to accomplish my card, such as finding out appropriate ideas, drafting, revising, editing and publishing"). Her capability was a representation of her awareness while learning to write. This awareness was a result of repeated utterances verbalized by her English teacher. In addition to the writing process, she learned about other linguistic features, such as grammar, lexical choices, and sentence structures. She realized that such knowledge was obtained from her teacher feedback written in her portfolio and her experiences to respond to the feedback ("Overall, this PBA was really helpful for us to learn from our experiences and his valuable feedback"). By the same token, student \# 2 reported that she perceived herself to have better control 
of her writing tasks. This occurred because of the pedagogical intervention provided by her English teacher, namely guiding her to keep checking and rechecking her portfolio regularly. Similar to student \# 1, the portfolio of student \# 2 was reviewed based on the macro and micro-skills of writing, namely ideas organization, grammatical errors, incorrect sentence structures, and inappropriate word choices. With these in mind, both students were guided to have awareness of monitoring their tasks autonomously and reflectively through the reviewed portfolios given by their teacher.

In line with the abovementioned issue, Nezakatgoo (2011) adds that the overall purpose of the portfolio assessment is to teach the students to monitor their learning progress. In this case, PBA offers flexibility to students to be able to self-monitor in performing their learning. Briefly stated, PBA enables them to enhance their language skills.

Self-monitoring is one of the learning strategies in learning. Rock (2005) argues that self-monitoring assists students to selfassess their behavior or learning process. Basically, self-monitoring provides immediate feedback to them. In addition, it allows teachers to evaluate the students' behavior. Furthermore, it generates students' awareness of their learning. This aligns with Cresswell's notion claiming that the students' self-monitoring technique increases their learning autonomy by providing them control over the initiation of feedback (Cresswell, 2000).

\section{Generating discipline, responsible and autonomous language learning attitudes}

Another evidence of creating, collecting, and archiving portfolios in PBA is to facilitate them to be more responsible, discipline, and autonomous. To illustrate, student \# 1 argued that he felt burdened the first time when creating and archiving her portfolios. This was caused by the regular activities obligating her to collect and store her assignments periodically and systematically. As a result, she might be exhausted and bored. Conversely, she realized that these activities were a breakthrough of teaching practices performed by her English teacher to help her become more responsible, disciplined, and independent ("However, this situation made me realize that PBA assigned by the teacher helped me to be more responsible, disciplined and independent").

Table 2. The extracts of generating discipline, responsible and autonomous language learning attitudes.

\section{Participants \\ Excerpts}

Student \#1 The first time when I accomplished my assignments through PBA, I felt that it was really burdening because I should collect and document my tasks periodically and systematically. However, this situation made me realize that PBA assigned by the teacher helped me to be more responsible, disciplined, and independent. These occurred since we frequently did this.

Student \#2 Making portfolios as the weekly tasks facilitated me to organize my time and activities. In this case, I can prioritize which one goes first and the next. I felt that I was able to reduce my dependence on my classmates gradually while finishing my English tasks. In other words, making portfolios shapes my learning autonomy and responsibility

(Transcriptions of Interview of Participants,

August 12, 2020)

Likewise, student \# 2 also uttered that PBA assisted her to have better time and activities management. As a matter of fact, she could prioritize her agendas starting 
from the highest priority to the least one ("In this case, I can prioritize which one goes first and next"). This provides a positive impact on a behavioral change. Besides, she maintained that her dependence on her classmates when accomplishing tasks remains to decrease gradually. Unfortunately, she did not give more specific information about how PBA could minimize her dependence and maximize her independence in terms of English language learning. She, further, contended that portfolios motivated her to be an autonomous and responsible language learner.

Benson \& Voller (1997) assert that students should be able to play their roles as social actors in their social contexts by being autonomous, logical, open-minded, disciplined, and responsible. By doing so, teachers are suggested to guide their students to realize their roles as social actors and agents of change possessing opportunities to optimize their learning outcomes through supportive learning attitudes, such as autonomy, discipline, and responsibility (Thanasoulas, 2000).

Given these facts, PBA is assumed to be an effective language assessment technique that not only enables students to be aware of self-monitoring but also disciplined, responsible and autonomous.

\section{Mitigating Perceptual Mismatches among Teacher and Students}

Table 3. The extracts of mitigating perceptual mismatches among teacher and students.

$$
\text { Participants } \quad \text { Excerpts }
$$

Student \#1

Before the teacher used PBA

in the English language

learning process, I personally perceived that I have different perspectives from him, especially in doing assignments. For instance, when we were required to make a collaborative writing task about descriptive texts, we thought that we must write one text about one topic by one student. Hence, each of us decided to have individual topics for our descriptive texts. We wrote it individually without paying attention to the importance of working together as instructed by the teacher. However, after the use of PBA, we can have clear instructions, known learning objectives, and valuable feedback to enhance our language skills.

\begin{tabular}{|c|c|}
\hline Student \#2 & $\begin{array}{l}\text { Sometimes, I felt I was } \\
\text { confused about the } \\
\text { assignments given by the } \\
\text { teacher. This is because the } \\
\text { content delivered and the } \\
\text { assignments were different. } \\
\text { I did not know why it } \\
\text { happened. Even, I did not } \\
\text { know why we learned this. } \\
\text { On the contrary, after he used } \\
\text { PBA in teaching English, I } \\
\text { understood the purposes of } \\
\text { a lesson learned and the } \\
\text { directions of assignments } \\
\text { since the teacher constantly } \\
\text { gave me feedback }\end{array}$ \\
\hline
\end{tabular}

(Transcriptions of Interview of Participants, August 12, 2020)

Another voice was verbalized by student \# 2 expressing that she was confused when doing her assignments due to the mismatched delivered content of learning materials and the assigned tasks. This was highly problematic since the teacher had not provided comprehensive directions on how to accomplish their assignments ("Sometimes, I felt I was confused about the assignments given by the teacher. This is because the content 
delivered and the assignments were different. I did not know why it happened"). On the other hand, she completely understood the connection between teaching purposes, teaching materials, and directions for accomplishing tasks. Additionally, she signified a similar viewpoint to student \# 1 claiming that successful attainments of learning objectives were caused by constant feedback addressed by the teacher to improve better learning outcomes during PBA.

Kumaravadivelu (2003) argues that the perceptual mismatches among teachers and students occur when the teachers' intentions and students' interpretation do not meet. This can take place due to insufficient exposure provided by the teachers. Another point occurs due to the distinct views on class aims, expectations, teachers' and learners' roles, class management, teaching procedures, and evaluation and inability to recognize students' names.

One of the strategies to overcome perceptual mismatches is to apply contextspecific techniques enabling students to familiarize themselves with given language learning materials, activities, and evaluation. Besides, clear instructions are viewed as an effective strategy to minimize the students' misinterpretation. By doing so, both teachers and students can position themselves in negotiated classroom interaction for the sake of attaining the expected learning objectives and optimal teaching goals (Kamali \& Behjat, 2018).

To sum up, PBA can bridge the gap between teacher and students in terms of perceptual mismatches in viewing what should be achieved, why should be achieved, and how to achieve particular learning objectives through miscellaneous tasks in PBA.

\section{CONCLUSION}

This study has reported how PBA as an alternative assessment in language learning enables students to have better learning attitudes and paradigmatic shift from scoring-oriented language learning to goalsoriented one. Specifically, the present study highlights the perceptions of Indonesian junior high school students on the deployment of PBA during English language learning. The findings disseminated that students perceived PBA to be able to develop their self-monitoring from their learning processes, generate their discipline, responsible and autonomous language learning attitudes, and mitigate their perceptual mismatches with their teacher. With these in mind, PBA can be a breakthrough for teachers to scaffold students in cultivating not only their cognitive engagement but also affective and behavioral ones during participating in English language learning practices. Similarly, this can provide them learning opportunities to review their strengths and weaknesses so that their learning autonomy and responsibility increase. Overall, this investigative attempt offers theoretical, empirical, and practical contributions to the principles of language learning and assessment, notably in the EFL context.

Although this study provides beneficial contributions, it demonstrates several limitations, such as single data collection technique (semi-structured interview), partial gendered-issue of participant (female students), inadequate participants, studentcentred investigative issue.

Future studies can triangulate the data collection by executing various techniques (e.g. interview, observation, and document analysis) to reach more credible and dependable investigative findings. Besides, 
recruiting more representative research participants and involving impartial gendered-issues (male and female students) are highly suggested. Equally important, conducting scrutiny from the teachercentred investigative lens can offer diverse perspectives on exploring a similar issue.

\section{ACKNOWLEDGEMENTS}

We would like to express our deepest gratitude to Yusup Supriyono (Head of English Education Department at Siliwangi University) and Arini Nurul Hidayati (A researcher of English Education Department at Siliwangi University) for their insightful feedback on the early version of this article and constant supports of accomplishing this scrutiny.

\section{REFERENCES}

Aghazadeh, Z., \& Soleimani, M. (2020). The Effect of E-portfolio on EFL Learners' Writing Accuracy, Fluency, and Complexity. The Reading Matrix: An International Online Journal, 20(2).

Arrafii, M. A. (2021). Indonesian teachers' conceptions of values and dimensions of assessment practice: The effect of teachers' characteristics. Teaching and Teacher Education, 98, 103245.

Baxter, P., \& Jack, S. (2008). Qualitative case study methodology: Study design and implementation for novice researchers. The Qualitative Report, 13(4), 544-559.

Bataineh, R., B. \& Obeiah, S., F. (2016). The Effect of Scaffolding and Portfolio Assessment on Jordanian EFL Students' Writing. Indonesian Journal of Applied Linguistics, 6(1), 12-19.

Benson, P. \& Voller, P. (1997). autonomy and independence in language learning. London: Longman.
Brown, H. D. (2001). Teaching by principles: an interactive approach to language pedagogy. Englewood Cliffs: Prentice-Hall.

Boyatzis, Richard, E. (1998). Transforming Qualitative Information: Thematic Analysis and Code Development. Thousand Oaks: Sage pub.

Braun, V., \& Clarke, V. (2006). Using thematic analysis in psychology. Qualitative Research in Psychology, 3(2). pp. 77-101.

Butrina, P., Le Vine, S., Henao, A., Sperling, J., \& Young, S. E. (2020). Municipal adaptation to changing curbside demands: Exploratory findings from semi-structured interviews with ten US cities. Transport Policy, 92, 1-7.

Cohen. (2006). Semi-structured interview. Robert Wood Johnson Foundation. Retrieved from: http://www.qualres.org/HomeSemi3629.html

Desyatova, Y. (2020). When inquiry is seen as resistance to change: expert teachers' experiences with the implementation of portfolio-based language assessment (PBLA). Critical Inquiry in Language Studies, 17(1), 42-63.

Efendi, Z., Usman, B., \& Muslem, A. (2017). Implementation of portfolio assessment in teaching English writing. English Education Journal, 8(2), 187198.

Farahian, M., \& Avarzamani, F. (2018). The Impact of Portfolio on EFL Students' Metacognition and Writing Performance. Cogent Education, 5(1).

García, A. L. C. (2020, September). The European Portfolio for Student Teachers of Languages: A Reflection and Communication Tool in Teacher Education Programmes. In International Conference on European Transnational 
Education (pp. 164-172). Springer, Cham.

Hamp-Lyons, L. (2001). Fourth generation writing assessment. Teoksessa T. Silva \& PK Matsuda (toim.) On second language writing. Mahwah, NJ: Lawrence Erlbaum Associates.

Han, S., Blank, J., \& Berson, I. R. (2020). Revisiting reflective practice in an era of teacher education reform: A self-study of an early childhood teacher education program. Journal of Early Childhood Teacher Education, 41(2), 162-182.

Hanifa, R. (2017). Teachers' view on the use of portfolio assessment in secondary schools in Indonesia. Date of access, 14(4), 75-86.

Harosid, H. (2019). Kurikulum 2013 Revisi $2017 . \quad$ Retrieved from https://dosen.ikipsiliwangi.ac.id/gambara n-umum-k13-revisi-2017-1.pdf

Harrel, M., C. \& Bradley, M., A. (2012). Data Collection Methods: SemiStructured Interviews and Focus Groups. Arlington, VA: RAND Corporation.

Hidayati, A. N., Dewi, N. S. N., Nurhaedin, E., \& Rosmala, D. (2020). Foreign Language Listening Anxiety in an Academic Listening Class. J-SHMIC: Journal of English for Academic, 7(2), 19.

Lam, R. (2014). "Promoting Self-regulated Learning through Portfolio Assessment: Testimony and Recommendations". Assessment \& Evaluation in Higher Education. 39(6), 699-714.

Lam, R. (2015). Assessment as learning: Examining a Cycle of Teaching, Learning, and Assessment of Writing in The Portfolio-Based Classroom. Studies in Higher Education.

Liu, Y. (2003). A case study of selected ESL students' experiences with writing portfolios in college composition courses. Unpublished doctoral dissertation, Ohio State University.

Martínez-Lirola, M. (2018). Multimodal teaching evaluation with a portfolio in a tertiary education language classroom. Argentinian Journal of Applied Linguistics, 6(1) 25-43.

Kamali, M., \& Behjat, F. (2018). Types of Perceptual Mismatches in Intermediate EFL Classes. Journal of Applied Linguistics and Language Research, 5(3), 156-168.

Kumaravadivelu, B. (2003). Beyond Methods: Macrostrategies for Language Learning: New Haven: Yale University Press.

Nezakatgoo. B. (2011) Portfolio as a Viable Alternative in Writing Assessment. Journal of Language Teaching and Research, 2(4), 747-756. https://doi.org/10.4304/jltr.2.4.747-756

Segaran, M. K., \& Hasim, Z. (2021). Selfregulated learning through ePortfolio: A meta-analysis. Malaysian Journal of Learning and Instruction, 18(1), 131156.

Sidebotham, M., Baird., K., Walters, C., \& Gamble, J. (2018). Preparing Student Midwives for Professional Practice: Evaluation of a Student E-Portfolio Assessment Item. Midwifery Education in Practice, 32, 84-89.

Sulistyo, T., Eltris, K. P. N., Mafulah, S., Budianto, S., Saiful, S., \& Heriyawati, D. F. (2020). Portfolio assessment: Learning outcomes and students' attitudes. Studies in English Language and Education, 7(1), 141-153.

Swicegood, P. (1994). Portfolio-based Assessment Practices. 30(1), 6-15. Retrieved from http://isc.sagepub.com

Syzdykova, Z., Koblandin, K., Mikhaylova, N., \& Akinina, O. (2021). Assessment of E-Portfolio in Higher Education. International Journal of Emerging 
Technologies in Learning (iJET), 16(2), 120-134.

Tandiana, T., S., Abdullah, F., \& Saputra, Y. (2020). Learning Multimodality through Genre-Based Multimodal Texts Analysis: Listening to Students' Voices. Vision: Journal for Language and Foreign Language Learning, 9(2), 101-114. doi:http://dx.doi.org/10.21580/vjv9i2540 6

Thanasoulas, D. (2000). What is learner autonomy and how can it be fostered. The Internet TESL Journal, 6(11), 37-48.

Tyas, P. A. (2020). Promoting students' autonomous learning using portfolio assessment in EFL writing class. JEES (Journal of English Educators Society), 5(1), 75-81.

Vass, V., \& Kiss, F. (2020, October). The Role of Competency Development in the Implementation of Portfolio-Based Education in Higher Education. In International Conference on Interactive Collaborative and Blended Learning (pp. 42-48). Springer, Cham.

Yin, R. K. (2003). Case study research: Design and methods (3rd Ed.). SAGE Publications Inc.

Xu, W., \& Zammit, K. (2020). Applying the thematic analysis to education: A hybrid approach to interpreting data in practitioner research. International Journal of Qualitative Methods, 19, 1609406920918810. 